\title{
Determination of the Effect of Magnesium Oxide Nanoparticles (MgO-NP) on in Vitro Culture of Cowpea (Vigna Unguiculata L. Walp)
}

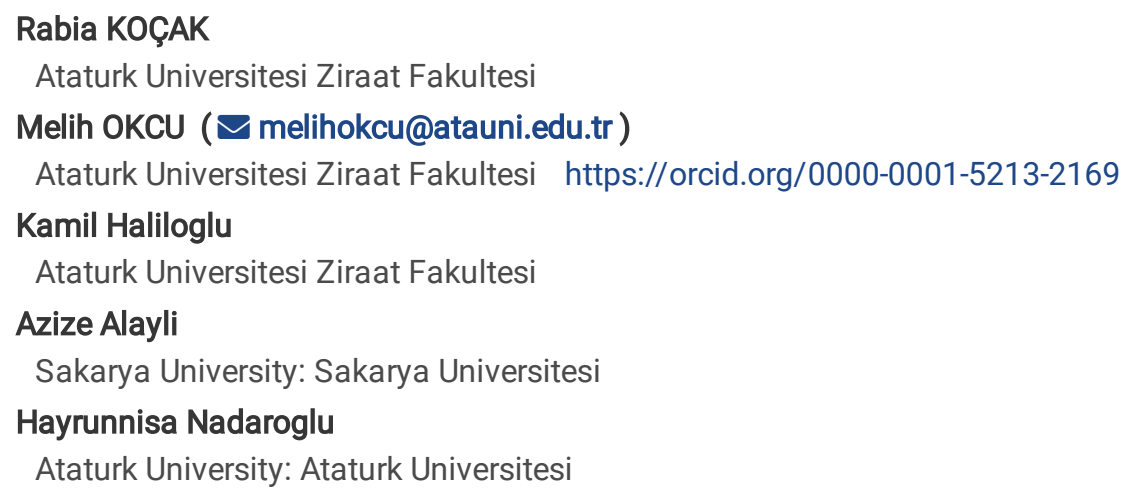

Research Article

Keywords: MgO-NPs, Nano fertilizer, cowpea feed, regeneration

Posted Date: December 16th, 2021

DOI: https://doi.org/10.21203/rs.3.rs-1088469/v1

License: (a) (1) This work is licensed under a Creative Commons Attribution 4.0 International License. Read Full License 


\section{Abstract}

This study was carried out to determine the effect of different doses of MgO nanoparticles (MgO-NP's) on in vitro regeneration of cowpea. MgO NPs used in the study were synthesized using walnut shell extract by green synthesis method. MgO nanoparticles with 35$40 \mathrm{~nm}$ size were used in this research. In the study, the effect of different doses of MgO NP applied to cowpea plant on all in vitro parameters was found to be significant.

Considering the parameters examined, the best results in morphogenesis were $185 \mathrm{mg} / \mathrm{L}, 370 \mathrm{mg} / \mathrm{L}$ and $555 \mathrm{mg} / \mathrm{L} \mathrm{MgO-NPs}$ applications, the highest shoot formation rate was obtained $82.50 \%$ with $555 \mathrm{mg} / \mathrm{L}(\mathrm{MgO}-\mathrm{NPs}$ ) and $72.50 \%$ with $370 \mathrm{mg} / \mathrm{L}$ (MgO-NPs). The highest mean values of shoot number, shoot number per explant and shoot length were observed in the application of $370 \mathrm{mg} / \mathrm{L}$ Mg0-NPs with 61.25, 17.50, and 2.075 (unit) respectively.

The best root formation rate was obtained from control and $370 \mathrm{mg} / \mathrm{L} \mathrm{MgO}$ application at a rate of $27.50 \%$. The highest values were 6.75 (pieces) and $370 \mathrm{mg} / \mathrm{L} \mathrm{MgO-NPs} \mathrm{in} \mathrm{the} \mathrm{number} \mathrm{of} \mathrm{roots} \mathrm{per} \mathrm{explant,} 555 \mathrm{mg} / \mathrm{L} \mathrm{MgO-NPs}$ with $10 \%$ in callus formation, and 1.575 (cm) and $370 \mathrm{mg} / \mathrm{L} \mathrm{MgO-NPs} \mathrm{in} \mathrm{root} \mathrm{length.} \mathrm{When} \mathrm{all} \mathrm{the} \mathrm{examined} \mathrm{parameters} \mathrm{were} \mathrm{evaluated,} \mathrm{it} \mathrm{was} \mathrm{determined} \mathrm{that} \mathrm{the} \mathrm{application} \mathrm{of} 370$ $\mathrm{mg} / \mathrm{L} \mathrm{MgO-NPs} \mathrm{gave} \mathrm{the} \mathrm{best} \mathrm{results} \mathrm{in} \mathrm{terms} \mathrm{of} \mathrm{in} \mathrm{vitro} \mathrm{parameters.}$

\section{Introduction}

Cowpea (Vigna unguiculata L. Walp) is a very common annual plant, especially in Africa, South America, Asia and the United States, and is one of the most important legumes worldwide (Xiong et al. 2016). It is a good pre-plant that has the ability to grow in poor soils and increases the yield of the next product with the help of nitrogen fixation (Miller et al. 1984; Pemberton and Smith 1990). Cowpea, which is considered as a green vegetable and dry grain in human nutrition and as a fodder in animal nutrition, belongs to the legume family and contains $2.0-4.3 \%$ protein in fresh beans and $4.5-5.0 \%$ in fresh grains. Protein content in dry cowpea grains that have reached maturity varies between $20.42-34.60 \%$ depending on the variety and environmental conditions. In addition, its grains contain $50-67 \%$ carbohydrates, $1.3 \%$ oil, $3.9 \%$ cellulose and 3.6\% ash (Vandemarket al.2014). The protein in its seeds is rich in Lysine and Tryptophan amino acids compared to cereal seeds, and insufficient in terms of Methionine and Cystine compared to animal proteins (Davis et al. 1991).

Nanotechnology, which is a multidisciplinary science, is a science that controls nano-sized materials and includes science and technology (Arnall 2003). In other words, it is defined as the existence of substances smaller than 100 nanometers in size and controlling them at the atomic level and making them useful (Bergeson 2004). Nanotechnology, which is an interdisciplinary research field developing in many different fields, covers pesticide distribution, nanosensors, pesticide degradation, use of micronutrients in agriculture, plant protection and nutrition, agricultural applications (Ghormade et al. 2011). Nanotechnology offers effective methods to protect soil health and conditions by helping to minimize agricultural waste and environmental pollution (Raliya et al. 2017; Duhan et al. 2017). Nanotechnological approaches can greatly improve the functioning of precision agriculture (Panpatte and Jhala 2019).

Magnesium oxide is an important inorganic material with a wide band range (Al-Gaashani et al. 2012). This material is used in many applications such as catalysis, catalyst supports, toxic waste reclamation, refractory materials and adsorbents, additive in heavy fuel oils, reflective and anti-reflective coatings, substrate such as superconducting and ferroelectric thin films, superconductors and lithiumion batteries (Ouraipryvan et al. 2009; Mirzaei and Davoodnia 2012). Nano MgO, on the other hand, has many special physical and chemical properties brought about by its nano size. With its size, nanoparticles can be used more by plant cells, induce plant growth, and have antimicrobial, antifungal and antiviral effects against pests.

Magnesium, which plays an important role in plant development and physiology, is a component of the synthetic chlorophyll pathway that regulates the activity of key photosynthetic enzymes in the chloroplast (Sawicki et al. 2017). Magnesium deficiency suppresses plant growth and decreases yield (Stagnari et al. 2011). Magnesium is a macronutrient that activates more enzymes than other nutrients (Epstein and Bloom 2005) and has structural and regulatory functions related to nucleophilic ligands in plants (Shaul 2002; Cakmak and Kirkby 2008). It is one of the essential elements in the function and synthesis of nucleic acids and ATP (Sreedhara and Cowan 2002; Igamberdiev and Kleczkowski 2015).

Nanotechnology is useful in the agricultural sector, in the form of nanopesticides and nanofertilizers. In addition, using this branch of science, the synthesized nanomaterials provide protection that is effective in controlling pests and pathogens that significantly affect the yield of the plant (Prasad et al. 2017). Wide applications of NPs in plant tissue culture include the elimination of microbial contaminants from explants, callus induction, organogenesis, somatic embryogenesis, somaclonal variation, genetic transformation and secondary 
metabolite development. Compounds can be developed by integrating the concept of nanotechnology into plant tissue culture techniques, synthesis, purification and desired plant-derived yield. Such approaches could have important industrial applications, as many phytochemicals are used as medicinal products.

Investigation of the effect of nanoparticles on in vitro propagation characters on cowpea plant, which has a great importance in human and animal nutrition, is a study that is lacking in the literature. In this context, it is aimed to determine the possible effects of callus formation on morphogenesis and plant regeneration by applying different doses of MgO NPs of cowpea plant.

\section{Material And Method \\ Synthesis of Mg Nanoparticles (MgO-NPs):}

MgO NPs were synthesized using walnut shell extract. The walnut shell extraction used for green synthesis was prepared with distilled water, and for this purpose, $25 \mathrm{~g}$ walnut shells were washed and crushed using the freeze-thaw technique in liquid nitrogen, $250 \mathrm{~mL}$ of distilled water was added and mixed in a magnetic stirrer for 1-2 hours. Then, the extract obtained by first filtering through cheesecloth and then filter paper was kept at $-25^{\circ} \mathrm{C}$ until use.0,1 $\mathrm{M} \mathrm{Mg}\left(\mathrm{NO}_{3}\right)_{2}$ çözeltisi bitkilerde $\mathrm{MgO}$ dönüşümü için aktif bir bileşik olarak kullanılmıştır. The formation of the synthesis was followed qualitatively and quantitatively by UV-Vis spectrophotometer. After the method optimization, the obtained nanoparticles were characterized. For this purpose, different morphological and molecular detection methods (SEM, FT-IR, XRD) were used. The obtained MgO-NPs were washed under vacuum using distilled water and ethanol and used in the reaction after drying in an oven. In the application range, after MgO-NPs were weighed and homogenized in pure water with the help of an ultrasonicator, they were used in plant in vitro experiments (Nadaroglu et al. 2017; Gultekin et al. 2017).

\section{Plant Material}

The cowpea cultivar, registered as "Ülkem" used in this study was obtained from Ondokuz Mayıs University and usually used for forage purposes. Forage cowpea seeds subjected to surface sterilization were kept in water overnight and the plumule parts of the embryos were removed and used as explants in the experiment.

\section{Tissue Culture Applications:}

MS medium, mineral salts and vitamins (Murashige and Skoog 1962) were used in the experiments. Magnesium and MgO-NPs in MS medium were exchanged with different concentrations. In the experiment, there were 5 treatments having different MgO NPs content. MS medium without MgO NPs in MS medium (control), amount of MgO NPs (1X - 370 mg/L), 0.5X (185 mg/L) MgO-NPs, $1 X$ ( 370 mg/L) MgO-NPs and $1.5 \mathrm{X}$ is (555 mg/L) MgO-NPs. Plumeles were cultured on MS mediums containing MgO-NPs previously prepared. The explants were kept in the dark at $24 \pm 1^{\circ} \mathrm{C}$ in callus initiation medium (MS salt and vitamins $+1.0 \mathrm{mg} / \mathrm{L}$ BAP) containing different Mg type and concentration for 4 weeks, and then they were placed in regeneration medium (MS salt and vitamins $+0.5 \mathrm{mg} / \mathrm{L}$ BAP) containing different MgO NPs type and concentration and kept under white fluorescent light (Preheat Daylight-42 $\mu$ mol photons $\mathrm{m}^{-2} \mathrm{~s}^{-1}$ ) for 4 weeks at $24 \pm 1^{\circ} \mathrm{C}$ in a 16 -hour light photo period. Morphogenesis, callus formation and rate measurements were made after the first 30 days. The number of shoots, shoot formation rate, shoot length $(\mathrm{mm})$, shoot number per explant, root formation rate, number of roots per explant and root length $(\mathrm{mm})$ parameters were measured after the second 30 days.

This study was carried out in complete randomized experimental design in factorial arrangement with four replications. Each petri dish was considered as an experimental unit and 10 cowpea plumula were cultured in each petri dish. Analysis of variand and Duncan multiple comparison test were computed with SPSS statistical analysis program (Version 20).

\section{Results And Discussion Surface morphological characterization of MgO NPs}

Surface characterization of MgO NPs was performed using SEM, FTIR and XRD analyzes and the results are given in Figures a,b and c. Chemical and mineralogical compositions of MgO NPs obtained by green synthesis method were determined using Metek, Apollo prime, 
Active area $10 \mathrm{~mm}^{2}$, Microscope examination S50, SE detector R580. SEM analysis determined that the MgO-NPs obtained by green synthesis were well dispersed and cubic (Figure 1A).

While the peaks at $39.2 \circ(111), 62.53(220), 77.8 \circ(311)$ and $81.7 \circ(222) 2 \theta \circ$ in the XRD graph in Figure $1 \mathrm{~B}$ belong to $\mathrm{Mg}(\mathrm{OH})_{2}$. The diffraction peaks are points represent cubic MgO-NPs at 42.76॰ (200)2 $\theta$ and 62.6॰ (220)2 (Nguyen et al. 2021).

FT-IR analysis is an effective technique used to identify possible peaks of MgO NPs and extract used for reduction of metal. FT-IR analysis of MgO NPs obtained by green synthesis is given in Figure 1C. As seen from the FTIR diagram, the wavelength between 400 and $4000 \mathrm{~cm}^{-1}$ was scanned. From the findings, it was determined that intense absorption peaks occurred at 3699, 3351, 2293, 1600, 1354, 1014,763 and $519 \mathrm{~cm}^{-1}$. While the peak observed at $3699 \mathrm{~cm}^{-1}$ belongs to the $-\mathrm{OH}$ band, the wide peak band observed at $3351 \mathrm{~cm}^{-1}$ indicates the presence of $-\mathrm{NH}_{2}$ and $-\mathrm{OH}$ groups in the medium. The peaks seen around $1600 \mathrm{~cm}-1$ indicate the presence of peaks defined as the primary amine group $(\mathrm{N}-\mathrm{H})$ overlapping with the amide and carboxylate group. The peak of the peak at $1354 \mathrm{~cm}^{-1}$ is matched with the $\mathrm{Mg}-\mathrm{OH}$ group, while all bands between 400-736 confirm the presence of MgO NPs. The size of MgO nanoparticles was determined to be 35-40 nm as a result of measurements and calculations. The obtained spectrum showed that the walnut shell extract had a high ability to reduce and stabilize MgO NPs. Similar findings were found in the FT-IR analyzes of MgO NPs obtained using some plant extracts in the literature, and they support our study (Amina et al. 2020; Asami et al. 2016; Dobrucka 2018; Karimi et al. 2015; Saied et al. 2021; Somanathan et al. 2016; Suresh et al. 2018).

\section{Morphogenesis}

The averages of the characters determined by the treatments of different concentrations of magnesium nanoparticles to the cowpea and the related variance analysis results are given in Table 1.

Table 1

Average values of the parameter ratios of magnesium nanoparticles at different doses examined in cowpea plant

\begin{tabular}{|c|c|c|c|c|c|c|c|c|c|}
\hline $\begin{array}{l}\text { Magnesium } \\
\text { Nanoparticle } \\
\text { Applications }\end{array}$ & Morphogenesis & $\begin{array}{l}\text { Shoot } \\
\text { Formation } \\
\text { Rate (\%) }\end{array}$ & $\begin{array}{l}\text { Number } \\
\text { of } \\
\text { shoots } \\
\text { (pieces) }\end{array}$ & $\begin{array}{l}\text { Number } \\
\text { of } \\
\text { Shoots } \\
\text { per } \\
\text { Explant } \\
\text { (piece) }\end{array}$ & $\begin{array}{l}\text { Shoot } \\
\text { length } \\
\text { (cm) }\end{array}$ & $\begin{array}{l}\text { Root } \\
\text { Formation } \\
\text { Rate (\%) }\end{array}$ & $\begin{array}{l}\text { Number } \\
\text { of roots } \\
\text { per } \\
\text { explant } \\
\text { (piece) }\end{array}$ & $\begin{array}{l}\text { Callus } \\
\text { Formation }\end{array}$ & $\begin{array}{l}\text { Root } \\
\text { Length } \\
\text { (cm) }\end{array}$ \\
\hline Control & 9.25 & $60 a b$ & $21.75 b$ & $6.50 \mathrm{bc}$ & $\begin{array}{l}0.4750 \\
\text { d }\end{array}$ & 27.50 & $\begin{array}{l}2.750000 \\
\text { b }\end{array}$ & $8 \mathrm{~b}$ & $\begin{array}{l}1.075000 \\
\text { b }\end{array}$ \\
\hline $\begin{array}{l}370 \mathrm{mg} / \mathrm{L} \\
\mathrm{MgO}-\mathrm{NPs}\end{array}$ & 9.25 & $42.50 \mathrm{bc}$ & 21.75 b & $6.75 \mathrm{bc}$ & $\begin{array}{l}1.2000 \\
\text { c }\end{array}$ & 27.50 & $\begin{array}{l}6.750000 \\
\mathbf{a}\end{array}$ & $9 a b$ & $\begin{array}{l}1.575000 \\
\text { a }\end{array}$ \\
\hline $\begin{array}{l}185 \mathrm{mg} / \mathrm{L} \\
\mathrm{MgO}-\mathrm{NPs}\end{array}$ & 10 & $30 \mathrm{c}$ & $3.75 b$ & $1.25 \mathrm{c}$ & $\begin{array}{l}0.1750 \\
\text { d }\end{array}$ & 19.75 & $\begin{array}{l}0.000900 \\
\text { C }\end{array}$ & $8.5 a b$ & $\begin{array}{l}0.000150 \\
\mathbf{c}\end{array}$ \\
\hline $\begin{array}{l}370 \mathrm{mg} / \mathrm{L} \\
\mathrm{MgO}-\mathrm{NPs}\end{array}$ & 10 & $72.50 \mathbf{a}$ & $61.25 \mathrm{a}$ & $17.50 \mathbf{a}$ & $\begin{array}{l}2.0750 \\
\mathbf{a}\end{array}$ & 22.50 & $\begin{array}{l}0.750050 \\
\text { bc }\end{array}$ & $9.50 \mathrm{ab}$ & $\begin{array}{l}0.275075 \\
\text { bc }\end{array}$ \\
\hline $\begin{array}{l}555 \mathrm{mg} / \mathrm{L} \\
\mathrm{MgO}-\mathrm{NPs}\end{array}$ & 10 & 82.50 a & $\begin{array}{l}36.25 \\
\mathrm{ab}\end{array}$ & $\begin{array}{l}10.00 \\
a b\end{array}$ & $\begin{array}{l}1.4500 \\
\text { b }\end{array}$ & $10.00 \mathbf{a}$ & $\begin{array}{l}0.750050 \\
\text { bc }\end{array}$ & $10.00 \mathbf{a}$ & $\begin{array}{l}0.20000 \\
\text { bc }\end{array}$ \\
\hline Mean & 9.7 & 57.50 & 28.95 & 8.40 & 1.0750 & 21.45 & 2.200028 & 9.00 & 0.625045 \\
\hline $\begin{array}{l}\text { Variation } \\
\text { Sources }\end{array}$ & SD & F Values & & & & & & & \\
\hline Replication & 4 & & & & & & & & \\
\hline $\begin{array}{l}\text { Magnesium } \\
\text { Nanoparticle } \\
\text { Applications }\end{array}$ & $41,350^{*}$ & $1837,5^{\star \star}$ & $3,459^{*}$ & $5,675^{\star *}$ & $88,901^{\star \star}$ & $1,905^{*}$ & $18,030^{\star \star}$ & $2,679 *$ & $20,402^{\star *}$ \\
\hline Error & 15 & & & & & & & & \\
\hline
\end{tabular}

These changes began to be observed after the first week of culture initiation. While the average number of explants showing morphogenesis was 9.25 at control $(0 \mathrm{mg} / \mathrm{L} \mathrm{Mg})$ and $370 \mathrm{mg} / \mathrm{L}$ doses, this number was decreased in Mg-Np applications (185 mg/L, 
$370 \mathrm{mg} / \mathrm{L}$ and $555 \mathrm{mg} / \mathrm{L} \mathrm{MgO-NPs})$. The number of morphogenesis was 10 . A significant $8.11 \%$ increase $(\mathrm{p}<0.05)$ in the number of morphogenesis was observed in $185 \mathrm{mg} / \mathrm{L}, 370 \mathrm{mg} / \mathrm{L}$ and $555 \mathrm{mg} / \mathrm{L} \mathrm{MgO-NPs}$ applications compared to the control.

Morphological changes such as tissue growth and tissue swelling were observed in the cultured cowpea explants (Figure 2; A, B).

\section{Callus formation:}

It has been observed that different MgO-NPs applications have significant effects on callus formation. In the study, the average callus formation determined according to magnesium nanoparticles in cowpea varied between 8 and 10. Callus formation reached the highest value with 10 units in the application of $555 \mathrm{mg} / \mathrm{L} \mathrm{MgO-NPs}$. This application was followed by an average of 9.5 to $370 \mathrm{mg} / \mathrm{L} \mathrm{MgO-NPs}$ and 9 to $370 \mathrm{mg} / \mathrm{L} \mathrm{MgO}$ applications. Different $\mathrm{Mg}$ treatments significantly increased callus formation compared to control. The highest increase was observed with $25 \%$ in $555 \mathrm{mg} / \mathrm{L}$ MgO-NPs application, followed by $18.75 \%$ with $370 \mathrm{mg} / \mathrm{L} \mathrm{MgO-NPs,} 12.50 \%$ with $370 \mathrm{mg} / \mathrm{L}$ $\mathrm{MgO}$ and $6.25 \%$ with $185 \mathrm{mg} / \mathrm{L} \mathrm{MgO-NPs}$ applications (Table 1).

\section{Shoot Formation:}

Different MgO-NPs applications (with or without NPs) created significant differences in shoot formation ( $<001)$. According to the effect of different doses of magnesium nanoparticles applied to the cowpea, shoot formation rates varied between $20.83 \%$ and $37.50 \%$. The highest value in shoot formation rate was obtained from $555 \mathrm{mg} / \mathrm{L} \mathrm{MgO-NPs}$ application with $82.50 \%$ and the lowest value was obtained from 185 mg/L MgO-NPs application with 30\%.

Shoot formation rate was $60 \%$ from the control application, $42.50 \%$ from the $370 \mathrm{mg} / \mathrm{L} \mathrm{MgO}$ application and $72.50 \%$ from the $370 \mathrm{mg} / \mathrm{L}$ MgO-NPs application. In the study, $370 \mathrm{mg} / \mathrm{L} \mathrm{MgO-NPs} \mathrm{and} 555 \mathrm{mg} / \mathrm{L} \mathrm{MgO-NPs} \mathrm{applications} \mathrm{increased} \mathrm{the} \mathrm{shoot} \mathrm{formation} \mathrm{rate} \mathrm{by}$ $20.83 \%$ and $37.50 \%$, respectively, while all other applications had a reducing effect compared to the control. This decrease was the highest with $50 \%$ with $185 \mathrm{mg} / \mathrm{L}$ MgO-NPs administration (Table 1).

\section{Number of Shoots:}

In the study, the highest number of shoots was obtained from 61.25 to $370 \mathrm{mg} / \mathrm{L} \mathrm{MgO-NPs}$ application, followed by 36.25 to $555 \mathrm{mg} / \mathrm{l}$ MgO-NPs application. Control and $370 \mathrm{mg} / \mathrm{LMgO}$ applications gave the same shoot number value as 21.75, while $185 \mathrm{mg} / \mathrm{L} \mathrm{MgO-NPs}$ application gave the lowest value with 3.75. Different magnesium nanoparticles increased the shoot number compared to the control treatment. Compared to the control, this increase in the number of shoots was $181.61 \%$ higher in the $370 \mathrm{mg} / \mathrm{L} \mathrm{MgO-NPs}$ application and $66.67 \%$ in the $555 \mathrm{mg} / \mathrm{L}$ MgO-NPs application. $185 \mathrm{mg} / \mathrm{L} \mathrm{MgO-NPs} \mathrm{application} \mathrm{showed} \mathrm{a} \mathrm{reducing} \mathrm{effect} \mathrm{(Table} \mathrm{1).}$

\section{Average number of shoots per explant (ANSPE):}

The mean values of the number of shoots per explant determined in the cowpea at different doses varied between 1.25-17.50. In terms of applications, the highest number of shoots per explant was obtained from the application of $370 \mathrm{mg} / \mathrm{L} \mathrm{MgO-NPs}$ with 17.50 units, and the lowest with 1.25 units from $185 \mathrm{mg} / \mathrm{L}$ MgO-NPs application. The number of shoots per explant obtained from other applications was determined as 6.50 in the control application, 6.75 in the $370 \mathrm{mg} / \mathrm{L} \mathrm{MgO}$ application and 10 in the $555 \mathrm{mg} / \mathrm{L} \mathrm{MgO-NPs}$. The decrease in the number of shoots per explant compared to the control application showed itself in the application of $185 \mathrm{mg} / \mathrm{L} \mathrm{MgO-NPs}$. Aasım (2010) reported that the value obtained by applying different doses of BAP and NAA to the number of shoots per explant in cowpea varies between 0.33 and 2.94, and the value obtained by the same researcher by applying different doses of TDZ varies between 1.89 and 2.78. The findings obtained from the study were higher than the results of Aasım (2010) (Table 1).

\section{Shoot length:}

In terms of shoot length, different $\mathrm{MgO}$ applications created significant differences. The shortest shoot was $0.18 \mathrm{~cm}$ in the $185 \mathrm{mg} / \mathrm{L}$ MgO-NPs application, and the longest shoot length was $2.08 \mathrm{~cm}$ in the $370 \mathrm{mg} / \mathrm{LMgO}-\mathrm{NPs}$ application. $370 \mathrm{mg} / \mathrm{L} \mathrm{MgO-NPs}$ application was followed by $555 \mathrm{mg} / \mathrm{L} \mathrm{MgO-NPs}(1.45 \mathrm{~cm})$ and $370 \mathrm{mg} / \mathrm{L} \mathrm{MgO}(1.20 \mathrm{~cm})$ applications. Except for the $185 \mathrm{mg} / \mathrm{L} \mathrm{MgO-NPs}$ application, the other $370 \mathrm{mg} / \mathrm{L} \mathrm{MgO}, 370 \mathrm{mg} / \mathrm{L} \mathrm{MgO-NPs}$ and $555 \mathrm{mg} / \mathrm{L} \mathrm{MgO-NPs}$ applications showed an increasing effect compared to the control.

The highest increase was obtained from the administration of $370 \mathrm{mg} / \mathrm{L} \mathrm{MgO-NPs}$ with $336.84 \%$ (Table 1). In studies on the subject, shoot length differs in cowpea plant and Aasım (2010) reported that shoot length varies between 2.28-3.98 cm with the application of different BAP and NAA doses. Kondak (2019) determined the effects of $\mathrm{MgO}$ nanoparticles and $\mathrm{MgSO}_{4}$ at different concentrations on shoot lengths in Odeska and Broken wheat varieties. The shoot lengths obtained were 15.05 and $15.48 \mathrm{~cm}$, respectively.

Page 5/11 


\section{Root formation rate:}

Different $\mathrm{Mg}$ applications had significant effects on root formation rate. The average root formation rate of the applied magnesium nanoparticles varied between 10 and $27.5 \%$. In terms of root formation rate, the highest value among magnesium nanoparticles was obtained from control and $370 \mathrm{mg} / \mathrm{L} \mathrm{MgO}$ applications with $27.50 \%$, this application was followed by $22.50 \%$ with $370 \mathrm{mg} / \mathrm{L} \mathrm{MgO-NPs}$ application and $19.75 \%$ with $185 \mathrm{mg} / \mathrm{L} \mathrm{MgO-NPs}$ applications. The lowest value was obtained from $10 \%$ to $555 \mathrm{mg} / \mathrm{L} \mathrm{MgO-NPs}$ application. The highest value was recorded in the application of $555 \mathrm{mg} / \mathrm{L} \mathrm{MgO-NPs,} \mathrm{with} \mathrm{a} 63.64 \%$ decrease in the variation of magnesium nanoparticles compared to the control (Table 1).

\section{Number of roots per explant (NRPE)}

Different MgO-NPs applications had significant effects in terms of root number per explant. While the maximum number of roots per explant determined in cowpea, where different doses of magnesium nanoparticles were applied, was obtained as 6.75 in the application of $370 \mathrm{mg} / \mathrm{L} \mathrm{MgO} \mathrm{NPs}$, this application was followed by 2.75 in the control application. When the research results were examined, the applied magnesium nanoparticles at different doses caused significant reductions compared to the control, except for the application of $370 \mathrm{mg} / \mathrm{L}$ MgO-NPs. The maximum decrease in the number of roots per explant was determined as $99.96 \%$ in the application of 185 $\mathrm{mg} / \mathrm{L}$ MgO-NPs. $370 \mathrm{mg} / \mathrm{L} \mathrm{MgO}$ application had an increasing effect on the number of roots per explant, and this increase was determined to be $145.45 \%$ (Table 1 ).

\section{Root length:}

According to the analysis of variance results, root length was significantly affected by different MgO-NPs applications. It was determined that the root length values obtained from the cowpea with different doses of magnesium nanoparticles varied between 0.0150 and $157.50 \mathrm{~mm}$. While the highest root length obtained from the applications was $157.50 \mathrm{~mm}$ from the $370 \mathrm{mg} / \mathrm{L} \mathrm{MgO}$ application, this application was followed by the control application with $107.50 \mathrm{~mm}$. In the $370 \mathrm{mg} / \mathrm{L} \mathrm{MgO}$ application, there was an increase of $46.51 \%$ compared to the control. A decrease was determined in all other applications except this application (Table 1).

Nanoparticles (NP) have begun to be used extensively in plant tissue culture studies. It is known that the kind, type, concentration and size of nanoparticles (NPs) are effective in studies conducted within the scope of plant tissue culture. Positive effects of NPs on callus induction, shoot regeneration and explant growth were observed. The growth characteristics of Tecomella undulata (Roxb.) were evaluated by combining silver NPs (5-80 $\mathrm{mg} \mathrm{L}^{-1}$ ) alone or with 6-benzyl amino-purine (6 BAP) and indole acetic acid (IAA). Addition of silver NPs $\left(10 \mathrm{mg} \mathrm{L}^{-1}\right)$ along with $2.5 \mathrm{mg} \mathrm{L}^{-1} \mathrm{BAP}$ and $0.1 \mathrm{mg} \mathrm{L}^{-1} \mathrm{IAA}$ in MS medium increased the number of fresh shoots per explant, the percentage of shoot-producing explant, as well as plant viability due to the effect on ethylene blocking. Concentrations of silver NPs above $60 \mathrm{mg} \mathrm{L}^{-1}$ resulted in reduced shoot regeneration (Aghdaei et al.2012).

Genady et al. 2016, shoot, root length and fresh weight of copper sulfate $\left(\mathrm{CuSO}_{4}\right)$ NPs on hazelnut seedlings in Verbena bipinnatif at concentrations of 5.10 and $15 \mu \mathrm{M} \mathrm{L}^{-1}$. They stated that $5 \mathrm{mg} \mathrm{L}^{-1} \mathrm{CuSO}_{4} \mathrm{NP}$ in MS medium increased shoot length (52\% compared to control), root length ( $21 \%$ compared to control), and fresh weight ( $39 \%$ compared to control). In this experiment, phenolic contents were increased by the use of $\mathrm{CuSO}_{4}$ NPs. Talankova-Sereda et al. 2016, in their study on Mentha longifolia L. with cobalt NPs $\left(0.8 \mathrm{mg} \mathrm{L}^{-1}\right)$ and copper $\left(0.5 \mathrm{mg} \mathrm{L}^{-1}\right)$ added to MS medium, the shoots of the plant, shoot length, rooting, and a significant difference in all evaluated parameters. increase was considered.

Effect of zinc oxide (ZnO) NPs (34 nm in size) at different concentrations $\left(0,0.1,1.0,10,100\right.$ or $\left.1000 \mathrm{mg} \mathrm{L}^{-1}\right)$ on microproagulated physiology and steviol glycoside (rebaudioside A and stevioside) production Stevia Rebaudiana Bertoni studied in the plant. The highest shoot formation percentage (89.6\%) was obtained from $1 \mathrm{mg} \mathrm{L}^{-1} \mathrm{ZnO}$ NP concentration. Moreover, a significant increase of steviol glycosides (almost doubling compared to control) was observed in microproagulated shoots grown under oxidative stress of $1 \mathrm{mg} \mathrm{L}^{-1}$ ZnO NPs according to HPLC results. However, antioxidant activities, formation of secondary metabolites, and physiological parameters showed a sudden decrease after crossing the threshold of $1 \mathrm{mg} \mathrm{L}^{-1} \mathrm{ZnO}$ NP concentration and decreased to a minimum at $1000 \mathrm{mg} \mathrm{L}^{-1}$ (Javed et al. 2017).

Different concentrations of silver or gold NPs $(1: 2,1: 3,2: 1$, and 3:1) alone or combined with naphthalene acetic acid (NAA) were evaluated for callus culture growth in Prunella vulgaris $L$. In combination with NAA (2.0 $\left.\mathrm{mg} \mathrm{L}^{-1}\right)$, callus proliferation (\%) of silver NPs (30 $\mu \mathrm{g} L-1$ ), silver-gold NPs (1: 2), and silver-gold NPs (2: 1) 100) compared to control (95\%) (Fazal et al. 2016). 
Addition of silver NPs onto MS medium evaluated callus induction in Solanum nigrum L. Different concentrations of aqueous silver NPs were used in MS medium (0, 2, 4 and $8 \mathrm{mg} \mathrm{L}^{-1}$ ). In the control treatment (no silver NPs), compact calli of white and greenish color were obtained after 10 days, while fragile watery calli of white, greenish or yellowish color were observed after 10-13 days on culture supplemented with silver NPs. In addition, when silver NPs were added to the medium, callus fresh weight and callus formation density increased, but deformations in callus morphology were found especially in high concentrations of NPs (Ewais et al. 2015). For callus induction from leaf explant, the effect of multi-walled carbon nanotubes $\left(25-500 \mathrm{mg} \mathrm{mL}^{-1}\right)$ with $\mathrm{B} 5$ nutrient medium was investigated and callus growth was observed significantly at a concentration of 25 to $50 \mathrm{mg} \mathrm{mL}^{-1}$. But at higher concentrations $\left(100-500 \mathrm{mg} \mathrm{mL}^{-1}\right)$ reduced callus biomass (Ghorbanpour and Hadian 2015).

From all the studies mentioned, it is possible to conclude that NPs have positive or negative effects on seedling, callus proliferation, shoot proliferation and somatic embryogenesis, depending on the concentration used in plant tissue culture studies, but there are still many parameters that need to be investigated to elucidate the mechanism of action of Nanoparticles. As a result; It was determined that different doses of MgO-NP caused significant changes on the characters studied in the cowpea plant. It has been determined that Mg doses have doses that will encourage plant growth. In particular, it was determined that $370 \mathrm{mg} / \mathrm{L} \mathrm{MgO-NPs}$ application gave the highest values among all parameters examined. It has been determined that MgO NP has a stimulating and regulating effect on plant growth in cowpea (Figure 2:C, D).

\section{Declarations}

\section{Funding}

The authors declare that no funds, grants, or other support were received during the preparation of this manuscript.

\section{Confllict of interest}

The authors declare that they have no conflict of interest.

\section{Competing Interests}

The authors have no relevant financial or non-financial interests to disclose.

\section{Contributions}

$\mathrm{KH}$ conceived and designed the experiments. RK and MO performed the experiments and analyzed the data. AA and HN wrote and revised the manuscript. $\mathrm{KH}$ and AA read and approved the final manuscript.

\section{Data availability}

The datasets generated during and/or analysed during the current study are available from the corresponding author on reasonable request.

\section{References}

1. Aasım M (2010) In vitro shoot regeneration and gene transfer in cowpea (Vigna unguiculata L.). PhD Thesis, Ankara University, Graduate School of Natural and Applied Sciences, Department of Field Crops.

2. Aghdaei M, Salehi H, Sarmast MK (2012) Effects of silver nanoparticles on Tecomella undulata Roxb.) seem, micropropagation. Adv Hortic Sci 26:21-24

3. Al-Gaashani R, Radiman S, Al-Douri Y, Tabet N, Daud AR (2012) Investigation of the optical properties of $\mathrm{Mg}(\mathrm{OH}) 2$ and $\mathrm{MgO}$ nanostructures obtained by microwave-assisted methods. Journalof Alloys and Compounds, 52, 7176.https://doi.org/10.1016/j.jallcom.2012.01.045.

4. Amina M, Al Musayeib NM, Alarfaj NA, El-Tohamy MF, Oraby H. F, Al Hamoud GA, Bukhari SI, Moubayed NMS (2020) Biogenic green synthesis of $\mathrm{MgO}$ nanoparticles using Saussurea costus biomasses for a comprehensive detection of their antimicrobial, cytotoxicity against MCF-7 breast cancer cells and photocatalysis potentials. PLOS ONE, 15(8), e0237567. doi: 10.1371/journal.pone.0237567 
5. Arnall AH (2003) Future technologies, today's choices nanotechnology, artificial intelligence and robotics; a technical, political and institutional map of emerging technologies. A Report for the Greenpeace Environmental Trust, London: Department of Environmental Science and Technology Environmental Policy and Management Group, Faculty of Life Sciences, Imperial College London, University of London.

6. Asami H, Tokugawa M, Masaki Y, Ishiuchi S, Gloaguen E, Seio K, Saigusa H, Fujii M, Sekine M, Mons M (2016) Effective Strategy for Conformer-Selective Detection of Short-Lived Excited State Species: Application to the IR Spectroscopy of the N1H Keto Tautomer of Guanine. The Journal of Physical Chemistry A, 120(14), 2179-2184. doi: 10.1021/acs.jpca.6b01194

7. Bergeson LL (2004) "The Regulatory Implications of Nanotechnology", Environmental Quality Management 14(1):71 - 82 DOI:10.1002/tqem.20027

8. Cakmak I, Kirkby EA (2008) Role of magnesium in carbon partioning and alleviating photooxidative damage, Physiol. Plant. 133, 692-704. Doi: 10.1111/j.1399-3054.2007.01042.x

9. Davis DW, Oelke EA, Oplinger ES, Doll JD, Hanson CV, Putnam DH (1991) Cowpea, University of Minnesota, Center for Alternative Plant and Animal Products and the Minnesota Extension Service.

10. Dobrucka R (2018). Synthesis of MgO Nanoparticles Using Artemisia abrotanum Herba Extract and Their Antioxidant and Photocatalytic Properties. Iranian Journal of Science and Technology, Transactions A: Science, 42(2), 547-555. doi: 10.1007/s40995-016-0076-x

11. Duhan JS, Kumar R, Kumar N, Kaur P, Nehra K, Duhan S (2017) Nanotechnology: the new perspective in precision agriculture Biotechnol Rep 15,11-23.

12. Epstein E, Bloom AJ (2005) Mineral nutrition of plants: Principles and perspectives, 2nd edn. Sinauer Associates, Sunderland

13. Ewais EA, Desouky SA, Elshazly EH (2015) Evaluation of callus responses of Solanum nigrum L. exposed to biologically synthesized silver nanoparticles. Nanosci Nanotechnol 5:45-56

14. Fazal H, Abbasi BH, Ahmad N, Ali M (2016) Elicitation of medicinally important antioxidant secondary metabolites with silver and gold nanoparticles in callus cultures of Prunella vulgaris L. Appl Biochem Biotechnol 180:1076-1092

15. Genady EA, Qaid EA, Fahmy AH (2016) Copper sulfate nanoparticales in vitro applications on Verbena bipinnatifida Nutt. Stimulating growth and total phenolic content increasments. Int. J. Pharm. Res. Allied Sci. 5, 196-202

16. Ghorbanpour M, Hadian J (2015) Multi-walled carbon nanotubes stimulate callus induction, secondary metabolites biosynthesis and antioxidant capacity in medicinal plant Satureja khuzestanica grown in vitro. Carbon 94:749-759

17. Ghormade V, Deshpande MV, Paknikar KM (2011) Perspectives for nano biotechnology enabled protection and nutrition of plants, Biotechnology Advances, 29, 792-803.

18. Giroto AS, Guimarães GG, Foschini M et al (2017) Role of Slow-release Nanocomposite Fertilizers on Nitrogen and Phosphate Availability in Soil[J], Scientific Reports, 7, 1-11.

19. Gultekin DD, Nadaroglu H, Alayli Gungor A, Horasan Kishali N. (2017) Biosynthesis and Characterization of Copper Oxide Nanoparticles using Cimin Grape (Vitis vinifera cv.) Extract. Int J Second Metab4: 77-84.Javed, R. Usman, M. Yucesan, B. Zia , Gurel, M. E.,2017. Effect of zinc oxide (ZnO) nanoparticles on physiology and steviol glycosides production in micropropagated shoots of Stevia rebaudiana Bertoni. Plant Physiol. Biochem. 110, 94-99

20. Igamberdiev AU, Kleczkowski LA (2015) Optimization of ATP synthase function in mitochondria and chloroplasts via the adenylate kinase equilibrium. Front Plant Sci 6:10. doi: 10. 33 89/fpls.2015.0001

21. Javed R, Usman M, Yucesan B, Zia M, Gurel E (2017) Effect of zinc oxide (ZnO) nanoparticles on physiology and steviol glycosides production in micropropagated shoots of Stevia rebaudiana Bertoni. Plant Physiol. Biochem. 110, 94-99

22. Karimi B, Khorasani M, Vali H, Vargas C, Luque R (2015) Palladium Nanoparticles Supported in the Nanospaces of ImidazoliumBased Bifunctional PMOs: The Role of Plugs in Selectivity Changeover in Aerobic Oxidation of Alcohols. ACS Catalysis, 5(7), 41894200. doi: $10.1021 /$ acscatal.5b00237

23. Kondak S (2019) The Effect of Magnesıum Oxıde (Mgo) Nanopartıcles and Magnesıum Sulphate (Mgso4) on Wheat (Triticum Aestivum L.) Plant Germınatıon. Master Thesis, Igdır University, Graduate School of Natural and Applied Sciences, Department of Field Crops.

24. Miller BC, Oplinger ES, Rand R, Peters J, Weess G (1984) Effect of planting date and plant population on sunflower performance. Argon.J. 76:511-515.

25. Mirzaei H, Davoodnia A (2012) Microwawe assisted sol-gel synthesis of MgO nanoparticles and their catalytic activity in the synthesis of hantzsch 1,4- dihydropyridines. Chinese Journal of Catalysis, 33, 1502-1507. 
26. Nadaroglu H. Alaylı Gungor, A, Ince S (2017) Synthesis of Nanoparticles by Green Synthesis Method. Int J Innov Res Rev 1(1), 6-9 1: 6-9.

27. Nalci OB, Nadaroglu H, Genc S et al (2020) The effects of MgS nanoparticles-Cisplatin-bio-conjugate on SH-SY5Y neuroblastoma cell line. Mol Biol Rep 47,9715-9723. https://doi.org/10.1007/s11033-020-05987-2.

28. Nguyen DTC, Dang HH, Vo DN, Bach LG, Nguyen TD, Tran TV (2021) Biogenic synthesis of MgO nanoparticles from different extracts (flower, bark, leaf) of Tecoma stans (L.) and their utilization in selected organic dyes treatment. Journal of Hazardous Materials, 404, 124146. doi: 10.1016/j.jhazmat.2020.124146

29. Ouraipryvan P, Sreethawong T, Chavadej S (2009) Synthesis crystalline MgO nanoparticle with mesporous-assembled structure via a surfactant-modified sol-gel process. Materials Letters, 63,1862-1865

30. Panpatte DG, Jhala YK (2019) Nanotechnology for Agriculture: Crop Production\&Protection. Springer Nature Singapore Pte Ltd. DOI: 10.1007/978-981-32-9374-8

31. Pemberton IJ, Smith GR (1990) Inheritance of ineffective nodulation in cowpea. Crop Science. 30:568-571.

32. Prasad R, Bhattacharya A, Nguyen D Q (2017) Nanotechnology in Sustainable Agriculture: Recent Developments, Challenges, and Perspectives. Front Microbiol.,1-13, doi.org/10.3389/fmicb.2017.01014

33. Raliya R, Saharan V, Dimkpa C, Biswas P (2017) Nanofertilizer for precision and sustainable agriculture: current state and future perspectives, J Agric Food Chem 66(26):6487-6503.

34. Saied E, Eid A, Hassan S, Salem S, Radwan A, Halawa M, Saleh F, Saad H, Saied E, Fouda A (2021) The Catalytic Activity of Biosynthesized Magnesium Oxide Nanoparticles (MgO-NPs) for Inhibiting the Growth of Pathogenic Microbes, Tanning Effluent Treatment, and Chromium Ion Removal. Catalysts, 11(7), 821. doi: 10.3390/catal11070821

35. Sawicki A, Zhou S, Kwiatkowski K (2017) 1-N-histidine Phosphorylation of ChID by the AAA+ Chll2 Stimulates Magnesium Chelatase Activity in Chlorophyll Synthesis. Biochemical Journal, 474,2 095.

36. Shaul O (2002) Magnesium transport and function in plants: the tip of the iceberg. Biometals, 15:309-323

37. Somanathan T, Krishna VM, Saravanan V, Kumar R, Kumar R (2016) MgO Nanoparticles for Effective Uptake and Release of Doxorubicin Drug: pH Sensitive Controlled Drug Release. Journal of Nanoscience and Nanotechnology, 16(9), 9421-9431. doi: 10.1166/jnn.2016.12164.

38. Sreedhara A,Cowan AJ (2002) Structural and catalytic roles for divalent magnesium in nucleic acid biochemistry. BioMetals 15: 211-223, DOI: 10. 1023/A: 1016070614042

39. Stagnari F, Onofri A, Pisante M (2011) Response of French Bean (Phaseolus vulgaris L.) Cultivars to Foliar Applications of Magnesium. Italian Joumal of Agronomy, 4, 101-110

40. Suresh J, Pradheesh G, Alexramani V, Sundrarajan M, Hong SI (2018) Green synthesis and characterization of hexagonal shaped MgO nanoparticles using insulin plant ( Costus pictus D. Don) leave extract and its antimicrobial as well as anticancer activity. Advanced Powder Technology, 29(7), 1685-1694. doi: 10.1016/j.apt.2018.04.003

41. Vandemark J G, Brick A M, Osorno M J, Kelly D J, Urrea A C (2014) Edible Grain Legumes. University of Nebreska-Lincoln. Panhandle Research and Extension Center. http://digitalcommons.unl.edu/panhandleresext/88

42. Xiong H, Shi A, Mou B, Qin J, Motes D, Lu W, Ma J, Weng Y, Yang W, Wu D (2016) Genetic diversity and population structure of cowpea (Vigna unguiculata L. Walp), Public Library of Science One, 11(8): e0160941, doi:10.1371/journal.pone.0160941.

43. Zhang SG, Yang YC, Gao B, Li YC, Liu ZG (2017) Superhydrophobic controlled-release fertilizers coated with bio-based polymers with organosilicon and nano-silica modifications, Journal of Materials Chemistry A 5(37):19943-19953, https://doi.org/10.1039/c7ta06014a .

\section{Figures}



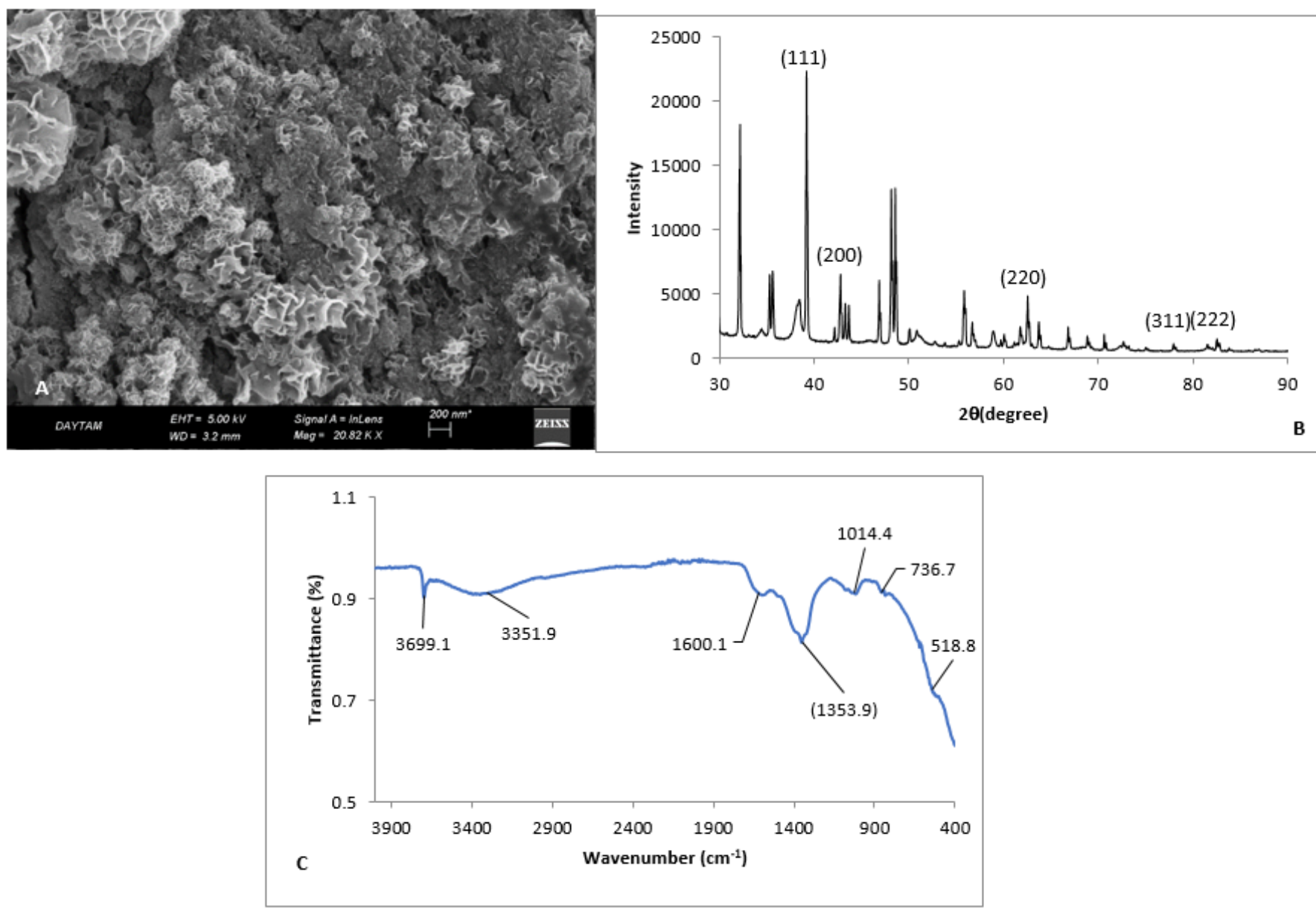

\section{Figure 1}

A) . SEM image of MgO-NPs synthesized by Walnut Shell extract, B) XRD pattern of MgO nanoparticles C) The FT-IR spectrum of green synthesized MgO-NPs using walnut Shell extract 

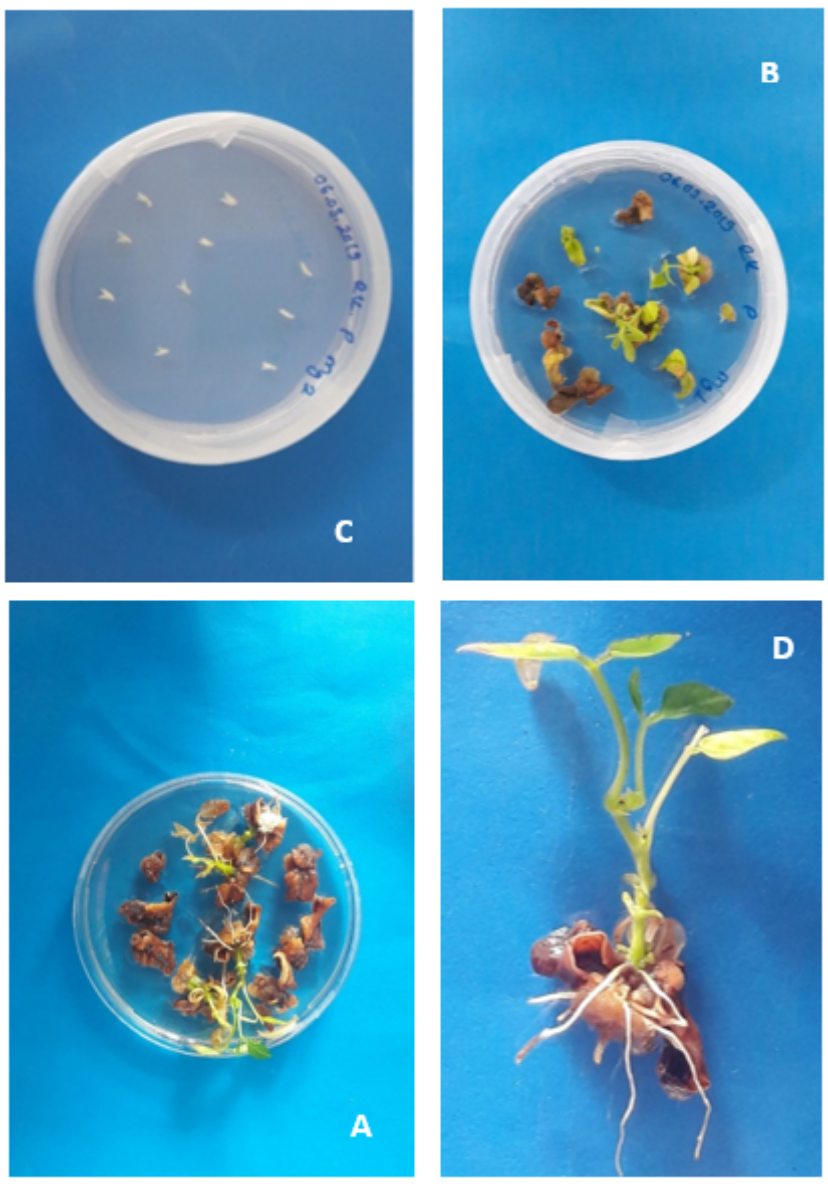

\section{Figure 2}

A) Cultured explants B) morphogenesis C) shoot and root formation D) Regenerated cow pea plantles. 